\title{
Sprawozdanie z obchodów 90-lecia istnienia łódzkiego oddziału Polskiego Towarzystwa Historycznego, Łódź, 9 grudnia 2017 r.
}

W dniu 9 grudnia 2017 r. w Sali Rady Wydziału Filozoficzno-Historycznego Uniwersytetu Łódzkiego (UŁ) odbył się Jubileusz 90-lecia istnienia Oddziału Łódzkiego Polskiego Towarzystwa Historycznego (OŁ PTH). Uczestniczyli w nim przedstawiciele Zarządu Głównego PTH $z$ prezesem prof. drem hab. Krzysztofem Mikulskim na czele, członkowie OŁ i jego kół terenowych, reprezentanci władz państwowych, miejskich i samorządowych, licznych instytucji naukowych i muzealnych (Oddziału Instytutu Pamięci Narodowej w Łodzi, Archiwum Państwowego w Łodzi, Muzeum Tradycji Niepodległościowych w Łodzi, Muzeum Miasta Łodzi, Muzeum Historycznych Pojazdów Militarnych i Techniki Motoryzacyjnej w Boczkach), wreszcie pracownicy Instytutu Historii, doktoranci i studenci UŁ, sympatycy PTH.

Uroczystość otworzyła prezes Oddziału PTH w Łodzi, prof. dr hab. Jolanta Daszyńska, która serdecznie powitała zaproszonych gości i wszystkich zebranych. Następnie głos zabrał Jego Magnificencja Rektor UŁ, prof. dr hab. Antoni Różalski. Pogratulował on OŁ PTH dotychczasowych osiągnięć. Stwierdził, że jego powstanie przyczyniło się do ukształtowania inteligencji humanistycznej w Łodzi. Działalność OŁ zaowocowała trwałymi dokonaniami, m.in. publikacjami monografii miast $z$ terenu województwa łódzkiego czy opracowaniem różnych wydarzeń historycznych. Podkreślił, ̇̇e w pracach Oddziału PTH w Łodzi brali i biora udział pracownicy UŁ, profesorowie, adiunkci, doktoranci, jak również absolwenci Wydziału Filozoficzno-Historycznego tej uczelni. Kończac, w imieniu własnym oraz Łódzkiego Towarzystwa Historycznego, którego jest członkiem, złożył Oł życzenia dalszych, wspaniałych sukcesów w pracy naukowej i popularyzacji wiedzy historycznej. 
Następnie głos zabrał senator Rzeczypospolitej Polskiej - Ryszard Bonisławski. Oznajmił, że dawka wiedzy, jaka czerpał w młodości $z$ przedwojennych wydawnictw sygnowanych przez Towarzystwo Historyczne, a także później, w dorosłym już życiu z tego wszystkiego, co było dorobkiem profesorów UŁ, m.in. Gryzeldy Missalowej $i$ innych, sprawiły, że zainteresowanie Łodzią znalazły swoje właściwe korzenie i dobry fundament. Mówił o tym, że w budynku Instytutu Historii UŁ jako student filologii polskiej miał liczne zajęcia $z$ historii. Pogratulował OŁ PTH dotychczasowego dorobku i wyraził nadzieję, że będzie on stale pomnażany. Wręczył na ręce Pani Prezes opasły tom poświęcony senatorom, którzy w czasie II wojny światowej stracili życie.

Jako kolejny wystapił dziekan Wydziału Filozoficzno-Historycznego UŁ, prof. dr hab. Maciej Kokoszko. Oznajmił krótko, że Wydział Filozoficzno-Historyczny naszej Almae Matris jest zaszczycony tym, że gości w swych murach PTH, i obiecał, że w przyszłości będzie dokładnie tak samo.

Po nim przemówił dyrektor Instytutu Historii, prof. dr hab. Dariusz Jeziorny. Wyraził zadowolenie $z$ faktu, że tak wielu członków OŁ jest zarazem pracownikami Instytutu Historii. Zauważył, że oddział ten ma dłuższą historię niż instytut. Pogratulował PTH dotychczasowych sukcesów i życzył, by jego działalność naukowa i popularyzatorska doprowadzała do wzrostu wiedzy historycznej następnych pokoleń.

Następnie głos zabrał prezes Zarządu Głównego PTH, prof. dr hab. Krzysztof Mikulski. Stwierdził, że jest mu niezmiernie miło uczestniczyć w obchodach jednego $z$ najstarszych (drugiego po Warszawie) i najliczniejszych oddziałów PTH w Polsce. To bardzo ważny oddział, a jednocześnie niesłychanie aktywny, znakomicie realizujacy od lat swoje posłannictwo wobec środowiska historycznego w zakresie pogłębiania i upowszechniania wiedzy na temat dziejów Łodzi i regionu. Dodał, że OŁ był organizatorem niesłychanie ważnego, XIV Powszechnego Zjazdu Historyków Polskich w 1989 r., jak również kilku walnych zgromadzeń delegatów PTH (ostatnie w 2015 r.). Członkowie tego oddziału sa bardzo aktywnymi członkami towarzystwa, uczestniczą w jego najważniejszych przedsięwzięciach, jak choćby Olimpiada Historyczna. Przypomniał, że $z$ tego środowiska wywodzi się jego następca i poprzednik na stanowisku prezesa Zarządu Głównego, prof. Jan Szymczak. Na zakończenie prof. K. Mikulski w imieniu własnym i obecnych na sali przedstawicieli Zarządów Głównego złożył życzenia i gratulacje dla OŁ PTH. 


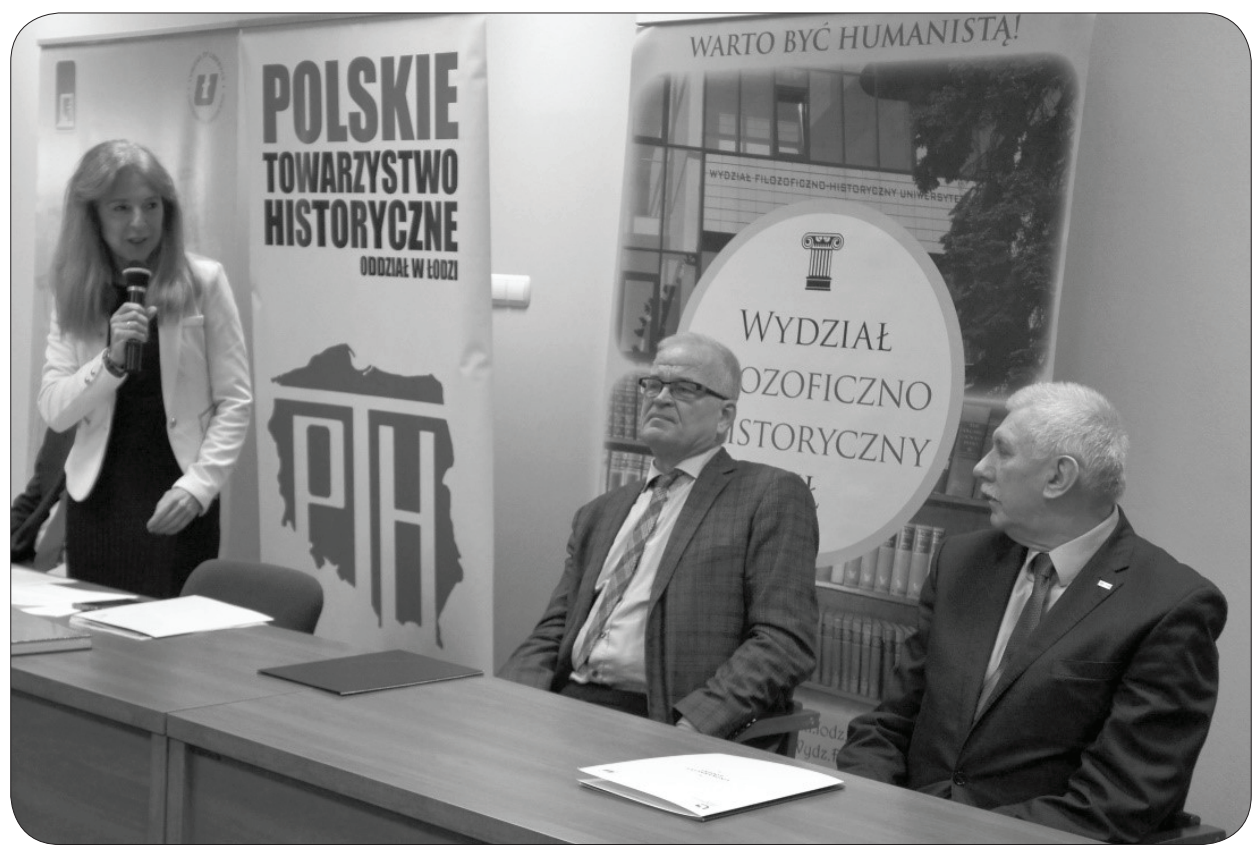

1. Obchody 90-lecia OŁ PTH (od lewej: prezes OŁ prof. dr hab. Jolanta Daszyńska, prezes Zarządu Głównego PTH prof. dr hab. Krzysztof Mikulski, Jego Magnificencja Rektor UŁ prof. dr hab. Antoni Różalski), fot. M. Karkocha

Z kolei odczytano list gratulacyjny Prezydent Miasta Łodzi Hanny Zdanowskiej oraz dyplom uznania prezesa PTH Oddział w Radomsku, dra Tomasza Nowaka.

W dalszej części spotkania wiceprezes OŁ prof. dr hab. Jarosław Kita przybliżył pokrótce historię i działalność tego oddziału. Zaakcentował, że jest to jeden $z$ pierwszych oddziałów PTH założonych jeszcze w okresie II Rzeczypospolitej (1927) i że obecnie jest to drugi po Warszawie pod względem liczebności oddział w kraju. Wskazał na dwie cechy charakterystyczne tego oddziału. Po pierwsze, powstał on w mieście typowo przemysłowym, wielokulturowym i pozbawionym wyższej uczelni, gdzie rolę inicjatorów-założycieli musiało odgrywać łódzkie środowisko nauczycieli szkół średnich z Zygmuntem Lorentzem i Jadwiga Krasicka na czele. Po drugie, włączył się on w pewien dyskurs toczący się wokół tego, czy oddziały mają być ściśle podporządkowane centrali, czy też mogą mieć charakter autonomiczny. Oddział w Łodzi stał na stanowisku, że pewne inicjatywy powinny być podejmowane samodzielnie, co widać zwłaszcza na przykładzie wydawania Polskiego słownika 


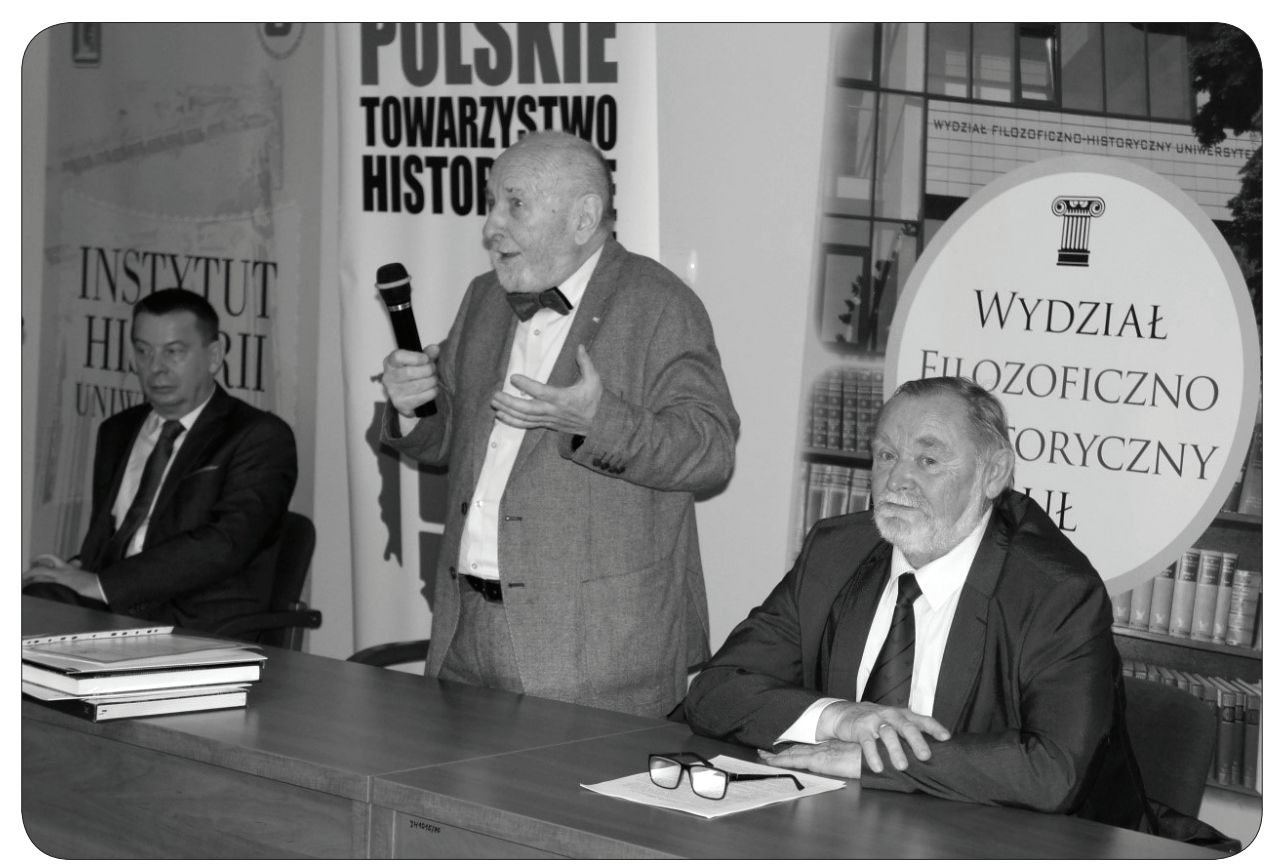

2. Przemówienie byłego prezesa OŁ PTH prof. dra hab. Wiesława Pusia.

Obok niego: prof. dr hab. Jarosław Kita (pierwszy z lewej)

i prof. dr hab. Jan Szymczak, fot. M. Karkocha

biograficznego. (Kwestia ta stała się zreszta powodem ostrego sporu między Zarządem Głównym we Lwowie a jego łódzką komórką). Przypomniał dalej, że OŁ jako jeden $z$ nielicznych wydawał swoje czasopismo - „Rocznik Łódzki Oddziału Łódzkiego Polskiego Towarzystwa Historycznego", ukazujący się od 1929 r. do dziś (od 1958 r. pod zmienionym tytułem „Rocznik Łódzki”). Do ważniejszych inicjatyw tego oddziału prof. J. Kita zaliczył działalność dydaktyczną oraz badania nad dziejami Łodzi i regionu łódzkiego, efektem których sa liczne publikacje o charakterze monograficznym. Wyraził nadzieję, że w przyszłości powstanie całościowe opracowanie ukazujące historię i działalność OŁ.

Następnie odbył się panel $z$ udziałem kolejnych prezesów OŁ PTH: prof. prof. Wiesława Pusia, Jana Szymczaka, Alicji Szymczak i Jolanty Daszyńskiej. Przedstawili oni najważniejsze momenty $z$ funkcjonowania oddziału podczas ich prezesury oraz wskazali na pewne istotne wydarzenia, w których brali udział. Profesor Wiesław Puś, pełniący funkcję prezesa w latach 1990-1991, przybliżył kulisy XIV Powszechnego Zjazdu Historyków w Łodzi (7-10 IX 1989), 


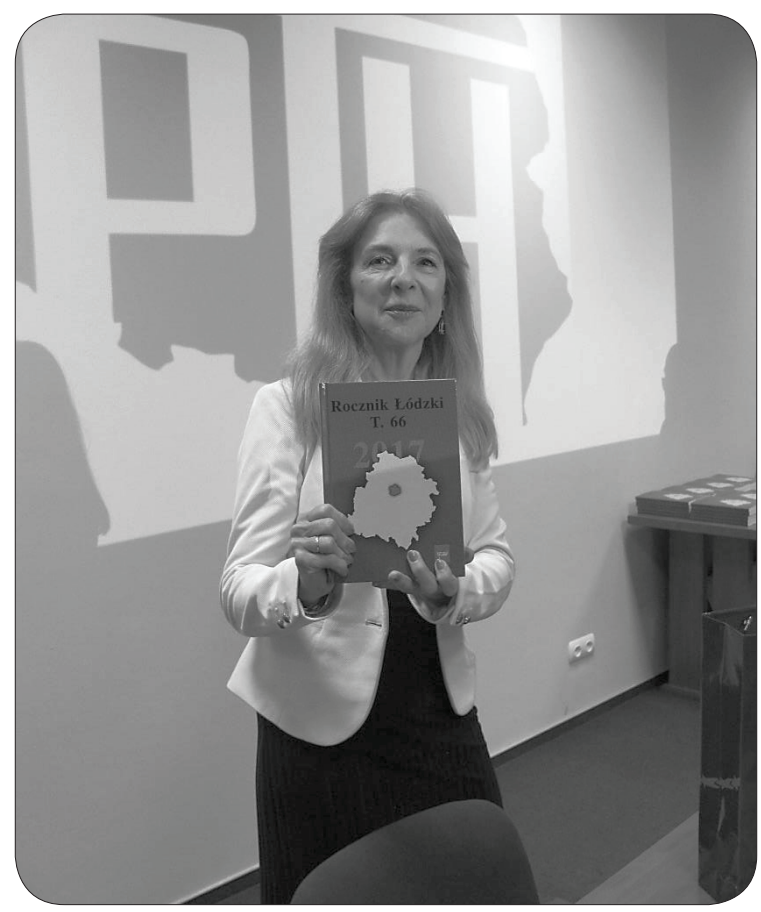

3. Prezes OŁ PTH prof. dr hab. Jolanta Daszyńska prezentująca najnowszy tom „Rocznika Łódzkiego" poświęcony 90-leciu tego oddziału, fot. J. Frenkel

którego był sekretarzem. Profesor Jan Szymczak - zwiąany z PTH od 1970 r., w latach zaś 1991-1997 prezes OŁ - mówił o tym, że jednym $z$ ważniejszych zadań w okresie jego pierwszej kadencji była sprawa „Rocznika Łódzkiego”. Tom XXIX tego czasopisma ukazał się bowiem w 1989 r., natomiast tom XL (jubileuszowy dla Ryszarda Rosina) dopiero w roku 1993. Również kolejny tom (XLI) był tomem specjalnym, poświęconym 75 rocznicy powstania województwa łódzkiego. Swoją druga kadencję w latach 1994-1997 prof. J. Szymczak określił jako „spokojniejsza”. Wydano wówczas monografię Uniejowa i zmieniono kolor okładki „Rocznika Łódzkiego" $z$ białego na bardziej sympatyczny niebieski.

Profesor Alicja Szymczak, prezes OŁ PTH w latach 2003-2009, przypomniała zebranym, że za jej zarządu zorganizowano 80-lecie działalności tego oddziału i wydano okolicznościowa publikację. Powstała ona głównie we współpracy nieżyjącej już prof. Marii Nartonowicz-Kot, która była „dobrym duchem” oddziału, wicepreze- 
sem w zarządzie i wieloletnim redaktorem „Rocznika Łódzkiego”. Profesor Szymczak poinformowała dalej, że najważniejszym wydarzeniem związanym $z$ jej działalnościa na stanowisku prezesa O€ był III Kongres Mediewistów Polskich w 2008 r., będący dużym wyzwaniem przede wszystkim ze względów logistycznych (ponad 250 uczestników). Stwierdziła też, że za jej prezesury kładziono duży nacisk na comiesięczne odczyty. Obowiązkiem historyka jest bowiem upowszechnienie wiedzy i dzielenie się wynikami badań $z$ innymi. Zwróciła także uwage na dwa inne aspekty działalności OŁ PTH: współpracę $z$ samorząami, czego efektem była publikacja kolejnych monografii miast $z$ terenów województwa łódzkiego, oraz współpracę ze szkołami. Ta ostatnia zaowocowała wspólnymi spotkaniami, na których dyskutowano ważkie problemy, trudne do nauczania w szkole. Na zakończenie prof. A. Szymczakowa podziękowała osobom wchodzacym do zarządu OŁ w okresie jej kadencji oraz tym wszystkim, którzy $z$ nią współpracowali.

Jako ostatnia wystapiła prof. Jolanta Daszyńska, określająca siebie mianem "walczącej prezes”. Wskazała ona 10 głównych zadań realizowanych przez OŁ za czasów pełnienia przez nią funkcji prezesa (od roku 2009). Sa to: 1) przypomnienie tematu „Operacja Łódzka” (uzyskano grant i zorganizowano konferencję naukowa poświęconą tej problematyce); 2) popularyzacja wspomnianego zagadnienia przez organizowanie konferencji naukowych i publikowanie prac $z$ tego zakresu (łącznie odbyły się cztery konferencje i opublikowano cztery książki); 3) opracowanie i wydanie drukiem kolejnych monografii miast $z$ terenów województwa łódzkiego: Głowna, Wielunia, Kutna, Sieradza, a także gminy Zadzim; 4) objęcie patronatem honorowym wielu przedsięwzięć, jak konkursy szkolne, konferencje studenckie („Wiosny historyków” i „Jesienie historyków”) czy inscenizacje historyczne; 5) udział w rekonstrukcjach historycznych i rozpowszechnianie samego zagadnienia; 6) kontynuowanie comiesięcznych odczytów, które miały bardziej nowoczesna formę (prezentacje multimedialne); 7) popularyzowanie wiedzy historycznej przez członków OŁ PTH na różnego rodzaju konferencjach i sympozjach naukowych; 8) zainicjowanie nowego cyklu spotkań pt. „Ludzie z pasja”; 9) przygotowanie następnych edycji Olimpiady Historycznej; 10) zorganizowanie Walnego Zgromadzenia Delegatów PTH w Łodzi w 2015 r. 
$\mathrm{Na}$ zakończenie spotkania głos zabrały osoby $z$ sali. Doktor Paweł Perzyna odczytał list gratulacyjny podpisany przez dyrektora Oddziału Instytutu Pamięci Narodowej w Łodzi, dra Dariusza Roguta. Były wiceprezydent Łodzi, a obecnie radny miasta Włodzimierz Tomaszewski złożył na ręce J. Daszyńskiej życzenia i kwiaty, a prof. Marian Drozdowski przekazal podziękowania i życzenia od prezesa Oddziału Słupskiego PTH, dra Tomasza Katafiasza. Dodać należy, że w czasie uroczystości wyświetlana była prezentacja multimedialna ukazująca historię i działalność OŁ, przygotowana przez dra Tomasza Pietrasa. Wszyscy uczestnicy otrzymali najnowszy, specjalny egzemplarz „Rocznika Łódzkiego” (tom LXVI), poświęcony 90-leciu tego oddziału.

Matgorzata Karkocha UNIWERSYTET ŁÓDZKI*

* Wydział Filozoficzno-Historyczny, Instytut Historii, Katedra Historii Nowożytnej, e-mail: malkarkocha@o2.pl. 